\title{
Distribution and availability of raw materials for production of Nepali handmade paper from Daphne species in Darchula district, Nepal
}

\begin{abstract}
D. K. Kharal ${ }^{1}$, B. N. Oli ${ }^{2}$ and I. Poudel ${ }^{3}$
The study, conducted in 2005 in Darchula district of the far western region of Nepal, aimed at assessing the distribution of Lokta plants (Daphne species) and the sustainable availability of their bark as a raw material for Nepali handmade paper. Stratified random sampling design was adopted for collecting primary data from 340 circular shaped sample plots. The study revealed asymmetric distribution and production of Lokta in different Range post areas of Darchula district. While the tree diameter at $30 \mathrm{~cm}$ from base $\left(D_{30}\right)$ varied from 1 to $18 \mathrm{~cm}$, the maximum tree height varied from 2.1 to $6 \mathrm{~m}$. On the basis of diameter class, about $87 \%$ of the bark weight was found to be of exploitable category. For the entire district of Darchula, the annual yield of Lokta bark for six years rotation amounted only to about two-third of the four years rotation. The study concludes that the stock of Lokta bark that prevails in the district can sustain promotion of Nepali paper production enterprises.
\end{abstract}

Key words: Annual yield, Non Timber Forest Product, rotation, Range post, sustainable production

$\mathbf{N}$ on Timber Forest Products (NTFPs) have a pivotal role in the rural as well as national economic development of Nepal (MPFS, 1989; MoFSC, 2004; NPC, 2010). In the country, approximately 10.13 thousand tons of NTFPs was extracted contributing to revenue of NRs. 67.38 million in the Fiscal Year 2002/03 alone (DoF, 2004). Lokta (Daphne bholua and D. papyracea) constitute one of the principal species among the limited NTFPs identified and traded in Nepal. The species has also been identified by the Master Plan for the Forestry Sector (MPFS) as one of the seven minor forest products available in the country (MPFS, 1989).

The distribution of Daphne bholua extends from Uttar Pradesh in India, through Nepal, southern Tibet, northern Assam, Bengal, Sikkim and Bhutan to south-west China. It occurs between 1800 to $3600 \mathrm{~m}$, and occasionally extends up to $4000 \mathrm{~m}$. Similarly, the distribution of $D$. papyracea which extends from Pakistan to central Nepal occurs between $1600 \mathrm{~m}$ and $2500 \mathrm{~m}$, and occasionally extends up to $3000 \mathrm{~m}$ (Jackson, 1987). In Nepal, Lokta is mainly used on a cottage industry scale for manufacturing handmade papers. Harvesting of Lokta bark and manufacturing of local paper both provide opportunities for creating local employment, thereby, providing potentials for generating income to sustain livelihoods of the local people. Realizing these facts, both the government and non-government sectors in Nepal have long been pursuing to promote the sustainable management of Lokta resources in the country.

Resource assessment is one of the important components of all sustainable management endeavours (FAO, 2010). The assessment provides clues for careful management of natural resources which is highly needed for preventing the resources being exhausted from over-exploitation. Haphazard practices of using resources without carrying out proper resource inventory only lead to exhaustion of such resources. This has happened with the Lokta resources of Nepal, which have been exploited heavily without carrying out any resource inventories in the past. Without assessing the growing stock, growth and yield patterns,

\footnotetext{
${ }^{1}$ Department of Forest Research and Survey, Kathmandu. Email: deepak_kharal@yahoo.com

${ }^{2}$ Mid-Western Regional Directorate of Forest, Surkhet, Nepal

${ }^{3}$ District Forest Office, Dang, Nepal
} 
Lokta plants, were exploited heavily only to find latter that no more raw materials are available for sustainable operation of paper factories. In Nepal, many paper factories had to be closed due to the scarcity of Lokta barks which are primarily used as raw materials for the paper factories (ANSAB, 2004).

At present, only a few literatures on Lokta resource assessment and management are available (Pokharel, 1989; FRD, 1991; Jeanrenaud and Thompson, 1986). Moreover, most of such literatures remain case specific, focusing only on the matters of resource assessment and the methodologies.

Lokta resources exist in 24 of the total 41 Village Development Committees (VDCs) of Darchula district. The Lokta containing 24 VDCs (including community forests) lie in the northern and eastern parts of the district. Despite their great potential for generating income and employment, no resource assessment work has yet been carried out for Lokta resources in Darchula district. A study on distribution and availability of Lokta plant (Daphne spp.) in the district has thus become an imperative.

The study primarily aimed at assessing the distribution of Daphne species in Darchula district and sustainable availability of their bark as a raw material for Nepali handmade paper. Since the Range posts are the basic unit of forest management and administration, the study was focused in assessing the resources existed within the Range post boundaries. It is anticipated that the study will provide meaningful guidance for sustainable and wise use of Lokta resources for production of Nepali handmade paper enterprises in the district. This will help enhance local as well as the national economy of the country through creation of increasing income generation opportunities for the local population.

\section{Materials and methods}

\section{Study site}

Darchula district is located in the far western development region of Nepal. It covers an area of $2329.6 \mathrm{~km}^{2}$ with wide range of altitudinal variation ranging from 357 to 7132 masl (MPRC, 2011). The district headquarter is situated in North $29^{\circ} 51^{\prime}$ latitude and East $80^{\circ} 34^{\prime}$ longitude. The district enjoys subtropical climate in the south to alpine and tundra in the northern belt. The topographic conditions vary from Mid mountain in the south and middle part and to High Himalayas in the north. Of the total forest cover of 79,538 ha of the district, 20, 064 ha have already been handed over to 226 Community Forest User Groups (CFUGs) (DFO Darchula, 2005). The district comprises eight Range posts. However the study area encompasses only six of them: Dethala, Joljibi, Khalanga, Khandeshwari, Khar and Rapla.

\section{Sampling design}

Stratified random sampling technique was used to collect information on distribution of Lokta plant as well as on availability of bark materials for Nepali handmade paper in the district. Qualitative categories of Lokta plants were considered as strata for the resources survey. Based on area proportion, the total numbers of sample plots were distributed in each stratum of the Lokta forest. Using participatory process, high density, medium density and low density strata of Lokta distribution areas were traced out in the topographic map of the district.

Like in Baglung Lokta Inventory (Mathema, 1990), circular plots of $25 \mathrm{~m}^{2}$ of $2.82 \mathrm{~m}$ radius were taken as sample plots for the measurement purposes. The first plot was laid out where the Lokta plant first appeared. The subsequent plots were established at $180^{\circ}$ south at an interval of 100 $\mathrm{m}$ in each stratum. Isolated patches and blocks of Lokta plant were considered while allocating the sample plots. Altogether, 340 sample plots were laid out in all study area and allocated them in different strata based on proportion to area principle.

\section{Plot measurement}

The measurement was carried out in 2005. Lokta plants smaller than $30 \mathrm{~cm}$ in height were considered as seedlings and as such, were only counted, without measuring. However, Lokta plants greater than $1 \mathrm{~m}$ in height were measured at diameter: $30 \mathrm{~cm}$ from the base $\left(\mathrm{d}_{30}\right)$; for bark biomass estimation The height of the plants and $\mathrm{D}_{30}$ were measured to precisions of $\pm 0.1 \mathrm{~m}$ and to $\pm 0.1 \mathrm{~cm}$ respectively. Randomly selected 20 
plots were measured for bark biomass estimation. Out of 6 Range posts; 2 plots from Dethala, 1 from Joljibi, 6 from Khalanga, 3 from Khar and 8 from Rapla were taken for bark biomass assessment. The number of stems and bark weight per plot were estimated at first, and later, average figures were derived at per hectare level. Lokta plants greater than $3 \mathrm{~cm} \mathrm{D}_{30}$ were included for the harvestable Lokta biomass estimation. Green weight of the bark was used to estimate the Lokta biomass.

\section{Data analysis}

At first, the compiled data were analyzed at plot level using the MS Excel software. Later on, per hectare figures were estimated using appropriate conversion.

\section{Results and discussion}

Stem distribution and density of Lokta plant Although, the participatory resource mapping phase had identified 7 Range posts and 24 VDCs as Lokta distribution areas, the sample survey during the field work could cover the data from 6 Range posts and 16 VDCs only. Stem distribution of Lokta in the studied Range posts is presented in table 1. The average number of stems per hectare was higher in Khar Range post and lower in Dethala. However, the total number of stems was found highest in Khandeswari Range post and lowest in Joljibi.

Table 1: Stem distribution by Range posts

\begin{tabular}{lrrrr}
\hline Range post & $\begin{array}{r}\text { Lokta } \\
\text { distribution area } \\
(\mathbf{~ h a})\end{array}$ & $\begin{array}{r}\text { No. of Sample plot } \\
\text { Average stems/ha }\end{array}$ & $\begin{array}{r}\text { Total stems in 000 } \\
\text { unit }\end{array}$ \\
\hline Dethala & 862.5 & 34 & 376 & 325 \\
Joljibi & 325.0 & 12 & 933 & 303 \\
Khalanga & 3475.0 & 85 & 767 & 2666 \\
Khandeswori & 5087.5 & 36 & 978 & 4974 \\
Khar & 2575.0 & 99 & 1026 & 2643 \\
Rapla & 2300.0 & 74 & 741 & 1703 \\
Total/average & 14625.0 & 340 & 826 & 12614 \\
\hline
\end{tabular}

Stem density of Lokta by Range post was found to be significantly different at $5 \%$ significance level $\left(\mathrm{p}=2 \cdot 13^{-06} ; \mathrm{df}=5\right)$. The total number of stems in the studied areas was more than 12 million.

\section{Stem distribution by diameter classes in Range post}

In the study area, the diameter of the Lokta plants ranged from $1 \mathrm{~cm}$ to $18 \mathrm{~cm}$ with about 5.1 $\mathrm{cm}$ mean value. Distribution of Lokta plant was divided into four diameter classes: $<2 \mathrm{~cm}, 2-4$ $\mathrm{cm}, 4-6 \mathrm{~cm}$ and $>6 \mathrm{~cm}$. Stem densities greatly varied in different diameter classes. Stem density of $<2 \mathrm{~cm}$ diameter was found as less as only about $10 \%$ of the total stems density. Whereas, stem density of diameter classes between 2 - 4 and $4-6$ $\mathrm{cm}$ were found almost equal representing about 31 $\%$ of the total density by each one. Table 2 depicts the stem density distribution by Range post and different diameter classes in the study area.

Table 2 clearly indicates that the Lokta distribution was highly dominated by bigger size diameter plants. There is a significant difference in the average density of Lokta by diameter classes $(\alpha=$ $0.05, \mathrm{p}=2.6^{-11}$. Table 3 presents stem distribution of Lokta plant on the basis of exploitable and nonexploitable diameter sizes. 
Table 2: Stem distribution of Lokta plant by Range post and diameter classes

\begin{tabular}{|c|c|c|c|c|c|}
\hline \multirow[t]{2}{*}{ Range post } & \multicolumn{4}{|c|}{ Per hectare stem density by diameter classes } & \multirow[t]{2}{*}{ Average } \\
\hline & $<2 \mathrm{~cm}$ & $2-4 \mathrm{~cm}$ & $4-6 \mathrm{~cm}$ & $6 \mathrm{~cm}$ & \\
\hline Dethala & 12 & 176 & 165 & 24 & 376 \\
\hline Joljibi & 0 & 400 & 367 & 167 & 933 \\
\hline Khalanga & 339 & 395 & 33 & 0 & 767 \\
\hline Khandeswori & 0 & 0 & 78 & 900 & 978 \\
\hline Khar & 8 & 327 & 493 & 198 & 1026 \\
\hline Rapla & 0 & 157 & 319 & 265 & 741 \\
\hline Average/ total & 88 & 260 & 259 & 219 & 826 \\
\hline
\end{tabular}

Table 3: Stem distribution by exploitable and non-exploitable diameter classes

\begin{tabular}{lllll}
\hline Range posts & $\begin{array}{l}\text { Distribution per ha } \\
<=3 \mathrm{~cm}\end{array}$ & $>3 \mathrm{~cm}$ & \multicolumn{2}{c}{$\begin{array}{l}\text { Distribution in range post in 000 unit } \\
<=3 \mathrm{~cm}\end{array}$} \\
\hline Dethala & 47 & 329 & 41 & 284 \\
Joljibi & 133 & 800 & 43 & 260 \\
Khalanga & 635 & 132 & 2208 & 458 \\
Khandeswari & 0 & 978 & 0 & 4974 \\
Khar & 105 & 921 & 271 & 2372 \\
Rapla & 38 & 703 & 87 & 1616 \\
Total/average & 207 & 619 & 2649 & 9965 \\
\hline
\end{tabular}

Acknowledging Mathema (1990), who has advised not to harvest Lokta plant with diameter of $<$ $3 \mathrm{~cm}$ at $\mathrm{D}_{30}$, this study Considered $\mathrm{D}_{30}>3 \mathrm{~cm}$ as exploitable size for Lokta. Per hectare stem distribution and total number of stem distribution in all the range posts covered by the study are presented in Table 3. It is evident from Table 3 that per hectare wise, Khandeswari Range post contained highest number of stems $>3$ $\mathrm{cm}$. Similarly, Khalanga Range post contained lowest number of stems with such sizes. Stems of exploitable size were found in maximum number in Khandeswari Range post and in minimum number in Joljibi Range post. Density wise, large sized Lokta stems (exploitable size) is highest in Khandeswari and smaller size Lokta plants are highest in Khalanga. Table 3 also shows that more than three-fourth (about $79 \%$ ) of the total stems bear exploitable sizes.

\section{Stem distribution by height classes}

In the past, it was a tradition to consider all stems $>2 \mathrm{~m}$ in height as exploitable size. However, this study has considered two categories of height: small $(<1.5 \mathrm{~m})$ and tall $(>2 \mathrm{~m})$. The reason for this is based on the flowering height and the age. Lokta plants flower when it reaches about a height of $1.5 \mathrm{~m}$ in about 7 years of time (NCFP, 1994). The height category wise number of stems per hectare as well as the number of stems present in Range posts covered by the study is given in table 4. Per hectare wise, the Khar Range post has the largest and Khalanga Range post, the lowest number of taller stems. Altogether, 7.7 million taller category stems, with highest number in Khandeswari and lowest number in Joljibi Range were found in all Range posts covered by the study. 
Table 4: Stem distribution by Range post and height classes

\begin{tabular}{|c|c|c|c|c|}
\hline \multirow[t]{2}{*}{ Range posts } & \multicolumn{2}{|c|}{ Stems/ha } & \multicolumn{2}{|c|}{ Stems in Range post in 000} \\
\hline & $<=1.5 \mathrm{~m}$ & $>1.5 \mathrm{~m}$ & $<=1.5 \mathrm{~m}$ & $>1.5 \mathrm{~m}$ \\
\hline Dethala & 82 & 294 & 71 & 254 \\
\hline Joljibi & 367 & 567 & 119 & 184 \\
\hline Khalanga & 659 & 108 & 2289 & 376 \\
\hline Khandeswori & 278 & 700 & 1413 & 3561 \\
\hline Khar & 162 & 865 & 416 & 2226 \\
\hline Rapla & 249 & 492 & 572 & 1131 \\
\hline $\begin{array}{l}\text { Average/ } \\
\text { total }\end{array}$ & 316 & 509 & 4881 & 7733 \\
\hline
\end{tabular}

The number of tall size stems is relatively less than that of big size stems (table 3). The share of tall and small size stems is about $61 \%$ and $39 \%$ respectively.

\section{Biomass of Lokta bark}

The average weight of the Lokta bark by diameter classes is given in table 5. The bark weight of an average stem was found to be about 112 grams. Similarly, per hectare bark weight at district level was found to be equivalent to about $110 \mathrm{~kg}$. A total of 1609 tons of Lokta bark has been estimated for the entire areas covered by the study.

FSRO (1984) had estimated the Lokta bark in five development regions of the country and found out less stocking in lower elevation $(5000-7500 \mathrm{ft})$ and higher stocking in upper elevation $(7500-10000 \mathrm{ft})$. The highest stocking was about $313 \mathrm{~kg}$ per hectare in the upper elevation of eastern developmentregion and lowest was about $0.268 \mathrm{~kg}$ per hectare in lower elevation of central development region. While the growing stock of Lokta bark in the farwestern development region was just about 25 $\mathrm{kg}$ per hectare in upper elevation and about $11 \mathrm{~kg}$ in lower elevation. But the study had remarked in its finding that per hectare figure may not be applicable for small areas due to very broad nature of survey.

About half of the total bark from a randomly selected Lokta distribution area comes from $>6$ $\mathrm{cm}$ diameter class. Around $30 \%$ of the bark may come from 2- $4 \mathrm{~cm}$ diameter class followed by $4-$ $6 \mathrm{~cm}$ diameter class and $<2 \mathrm{~cm}$ diameter class. There is highly significant difference in the mean per hectare bark biomass of different diameter classes in the district $\left(\alpha=0.05, \mathrm{p}=7.8^{-6}\right)$.

\section{Exploitable bark biomass}

It would be convenient for managers if the total Lokta bark is separated into exploitable and nonexploitable categories. Lokta stems with more than $3 \mathrm{~cm}$ were considered as exploitable size in this study. In the earlier practices, the stems with more than $2 \mathrm{~m}$ in height were considered as exploitable size (FS, 1983). The exploitable and non-exploitable bark biomass of Lokta plant in all studied Range posts is given in table 6 .

Table 5: Biomass stock of Lokta bark

\begin{tabular}{ccrr}
\hline Dia. Classes & \multicolumn{2}{c}{ Average bark biomass } & $\begin{array}{r}\text { Total weight in } \\
\text { District (tons) }\end{array}$ \\
\cline { 2 - 4 } & Per ha (kg) & Per stem (gram) & 89.8 \\
\hline$<=2 \mathrm{~cm}$ & 6.1 & 43.9 & 461.9 \\
$2-4 \mathrm{~cm}$ & 31.6 & 65.8 & 247.2 \\
$4-6 \mathrm{~cm}$ & 16.9 & 120.7 & 810.2 \\
$>6 \mathrm{~cm}$ & 55.4 & 251.8 & $\mathbf{1 6 0 9 . 0}$ \\
Average/total & 110.0 & $\mathbf{1 1 2 . 3}$ & \\
\hline
\end{tabular}


Table 6: Bark biomass of Lokta plant by stem sizes

\begin{tabular}{|c|c|c|c|c|}
\hline \multirow[t]{2}{*}{ Range post } & \multirow{2}{*}{$\begin{array}{c}\text { Area } \\
\text { (ha) }\end{array}$} & \multicolumn{2}{|c|}{ Bark biomass (tons) } & \multirow{2}{*}{$\begin{array}{c}\text { Total bark biomass } \\
\text { (tons) }\end{array}$} \\
\hline & & Non exploitable size & Exploitable size & \\
\hline Dethala & 862.5 & 17.5 & 77.4 & 94.9 \\
\hline Joljibi & 325.0 & 6.6 & 29.2 & 35.8 \\
\hline Khalanga & 3475.0 & 70.4 & 311.9 & 382.3 \\
\hline Khandeswari & 5087.5 & 103.1 & 456.7 & 559.7 \\
\hline Khar & 2575.0 & 52.2 & 231.1 & 283.3 \\
\hline Rapla & 2300.0 & 46.6 & 206.4 & 253.0 \\
\hline Grand total & 14625.0 & 296.3 & 1312.7 & 1609.0 \\
\hline
\end{tabular}

The per hectare average bark biomass of nonexploitable and exploitable categories were about $20 \mathrm{~kg}$ and $90 \mathrm{~kg}$ respectively, amounting to about $110 \mathrm{~kg}$ per hectare at district level. The total bark biomass from exploitable size of Lokta stem was found higher in Khandeswari Range post and lower in Joljibi (Table 6).

\section{Estimation of annual production}

Two types of rotations: four years and six years, have generally been recommended for Lokta bark harvesting (Mathema, 1990; FSRO, 1984; FS, 1983). A minimum of four years rotation should be maintained to provide minimum regeneration period for establishment. Six years rotation ensures more sustainable production of Lokta bark compared to four years rotation. The total production of the Lokta bark from the exploitable
Annual production is based on per hectare annual yields of Lokta bark which is about $22 \mathrm{~kg}$ in four years rotation period and $15 \mathrm{~kg}$ in six years rotation period. About $87 \%$ of the bark weight was found in exploitable category on the basis of diameter class. The annual yield of Lokta bark from six years rotation for the whole district is only about two-third of the four years rotation.

\section{Conclusion}

The distribution of Daphne spp. varies greatly by Range posts in Darchula district, both in terms of per hectare and total stems. The per hectare average bark biomass from exploitable stem category was about $90 \mathrm{~kg}$ at district level which is about $87 \%$ of the total bark biomass. The annual yield of Lokta bark from six years rotation is about $15 \mathrm{~kg}$ per hectare for the whole district which is only about two-third of the four years rotation. Nepali handmade paper production

Table 7: Annual production of Lokta bark based on 4 and 6 years rotation

\begin{tabular}{lrrr} 
Rangepost & Area & \multicolumn{2}{c}{ Annual production (tons) } \\
\hline & (ha) & 4 years & 6 years \\
\cline { 3 - 4 } Dethala & 862.5 & 19.4 & 12.9 \\
\hline Joljibi & 325.0 & 7.3 & 4.9 \\
Khalanga & 3475.0 & 78.0 & 52.0 \\
Khandeswori & 5087.5 & 114.2 & 76.1 \\
Khar & 2575.0 & 57.8 & 38.5 \\
Rapla & 2300.0 & 51.6 & 34.4 \\
Grand total & 14625.0 & 328.2 & 218.8
\end{tabular}

size of the stem based on diameter classes for four years and six years rotations are presented in table 7. enterprises can be developed in Darchula district from annual yield production based on six years rotation which might support the livelihood and income level of the rural people in the district. 


\section{Acknowledgement}

We are thankful to ANSAB for providing financial support to conduct the study. We would also like to appreciate the District Forest Office Darchula for facilitating the field work.

\section{References}

ANSAB. 2004. Non Timber Forest Products in Newspaper (In Nepali). Asia Network for Sustainable Agriculture and Bioresources (ANSAB), Kathmandu, Nepal.

DFO Darchula. 2005. District Forest Office, Darchula district, Khalanga, Nepal.

DoF. 2004. Hamro Ban (In Nepali). Department of Forests. Kathmandu, Nepal.

FAO. 2010. Global Forest Resource Assessment. United Nations Food and Agricultural Organization. Rome, Italy.

FRD, 1991. Annual Report 1990/91. NepalUK Forestry Research Project. Kathmandu, Nepal.

FS. 1983. Forest Management Plan for Sustainable Production and Utilization of Lokta Biomass in Hatia Range Post, Baglung district, Nepal.

FSRO, 1984. Preliminary Survey Report of Lokta Vegetation. Publication No. 41. Forest Survey and Research Office, Kathmandu, Nepal.

Jackson, J. K. 1987. Manual of Afforestation in Nepal. 2nd edition. Forest Research and Survey Centre, Kathmandu, Nepal.
Jeanrenaud J. P. and Thompson, I. J.1986. Daphne (Lokta), bark biomass production: management implications for paper making in Nepal. Commonwealth Forestry Review 65 (2): 117-130.

Mathema, P. 1990. Baglung Lokta Inventory Report. Forestry Research Division. Forest Research and Survey Centre, Kathmandu, Nepal.

MoFSC. 2004. Herbs and Non Timber Forest Products Development Policy. Ministry of Forests and Soil Conservation. Government of Nepal, Kathmandu, Nepal.

MPFS. 1989. Master Plan for the Forestry Sector. HMG/ ADB/ FINNIDA, Kathmandu, Nepal.

MPRC. 2011. District Development Profile of Nepal (2010/11): A Socio-economic database of Nepal. Mega Publication and Research Centre, Kathmandu, Nepal.

NCFP. 1994. Lokta (Daphne Species): The Supply Situation in Basantapur Area. Nepal-UK Community Forestry Project. Kathmandu, Nepal.

NPC. 2010. Three Years Plan (2010-2013). National Planning Commission. Government of Nepal. Kathmandu, Nepal.

Pokharel, R. K. 1989. Production of hand-made paper from Lokta in Sankhuwasabha. Banko Janakari 2 (2): 145-148. 